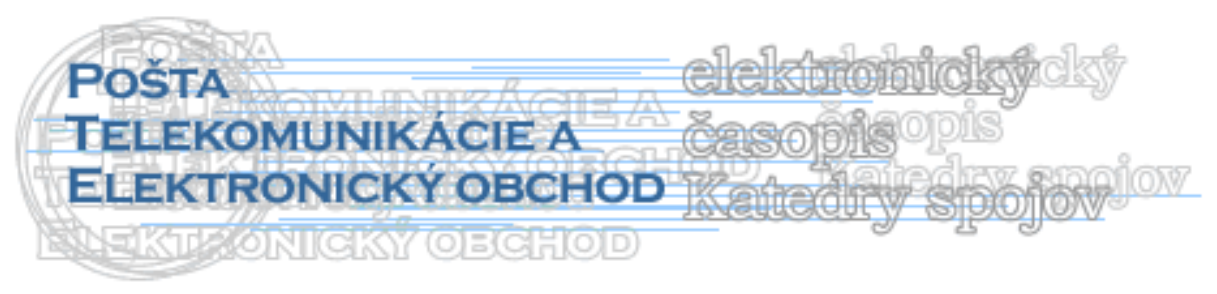

\title{
SMEROVANIE K ZNALOSTNÉMU MANAŽMENTU
}

\author{
Milan Kubiček ${ }^{1}$
}

\section{Úvod}

Súčasná doba, o ktorej hovoríme ako o dobe globalizácie, je typická zvyšujúcou sa konkurencieschopnost'ou, rastom technickej náročnosti výroby, otváraním sa trhov atd'., v ktorej sa udržia na trhu iba podniky ktoré sú dostatočne flexibilné. Začlenenie Slovenskej republiky do Európskej únie spôsobilo, že aj my sme vystavení týmto faktorom a ak sa chceme plnohodnotne zapojit' do európskeho ekonomického priestoru musia sa sledované podniky snažit' byt' konkurencieschopné. V tejto súvislosti je potrebné zachytit' aj nastupujúce trendy manažmentu. Trendy a nové prístupy k manažmentu neustále prichádzajú a odchádzajú, avšak problémy a výzvy zostávajú.

\section{História}

Ak by sme sa mali pozriet' dozadu, tak by sme zistili že za posledné štyri desat'ročia to boli hlavne štyri hlavné manažérske trendy, ktoré boli na výslní. Prvým z nich bolo plánovanie. Myšlienka centralizovaného plánovania bola zavrhnutá po rozpade Sovietskeho zväzu. Niektorí vyznávajú názor, že takéto plánovanie je nielen nerozumné ale aj nemožné. Avšak od všetkých manažérov sa dnes očakáva že sa stanú dobrými plánovačmi, pretože vediet' dobre plánovat' je vel'mi vzácne sa vyskytujúca schopnost'. Čo sa týka samotných niekdajších plánovačov, tí sa dobre uplatnili voblasti účtovníctva alebo v poradenských organizáciách. [11]

Ďalším trendom, ktorý sa ukázal skvelým v teórii, ale o to horším v praxi je $\mathbf{B P R}$ Business Process Re-engineering. Ide o prebudovanie a nové navrhnutie podniku. Ciel'om je navrhnút' podnik aj odvetvie pôsobenia s prijatím opatrení, na ktoré by si netrúfli konkurenti. Pri takomto prehodnocovaní je dôležité si položit' zásadné otázky:

- aká by mala byt' právna forma pre podnik takéhoto druhu,

- akých aktivít sa môže podnik zbavit',

- aké dôsledky to bude mat' na zamestnancov podniku.

Jedným z dôvodov prečo vyzdvihovaný reengineering nemal požadovaný efekt je aspekt, ktorým sa reengineering vyznačoval a to mechanickým riadením. Tento aspekt neuznával úlohu l'udského kapitálu. Aj tento fakt zapríčinil na Slovensku škody, ked' sa mechanicky prepúšs'alo bez ohl'adu na intelektuálny kapitál vo firmách, ked' sa zlikvidovala vedecko-výskumná základňa, konštrukčné a výskumné pracoviská priemyselných odvetví, ktoré teraz chýbajú v konkurenčnom zápase o trhy. [11]

\footnotetext{
${ }^{1}$ Ing. Milan Kubiček, Žilinská univerzita v Žiline, Fakulta prevádzky a ekonomiky dopravy a spojov, Katedra spojov, Univerzitná 1, 01026 Žilina, tel.: 041/513 3145, e-mail: Milan.Kubicek@fpedas.uniza.sk,
} 
Tretím trendom uplatňovaným v minulosti bol TQM teda Total Quality Management. Ide o klasický príklad dobrej myšlienky, ktorá po čase dostala trpkú príchut'. Deming - jeden z významných myslitel'ov manažmentu a zakladatel' manažmentu kvality učil Japoncov filozofii TQM a kontinuálnemu zlepšovanie - kaizen. Ked' sa však pokúsili tieto metódy zavádzat' vo svojich podnikoch západní priemyselníci, dosahovali často horšie výsledky a iniciatíva TQM sa ukázala ako menej produktívna ako sa očakávalo. O tom že uplatňovanie TQM hrá významnú úlohu pri zvyšovaní konkurencieschopnosti nikto nepochybuje, ale aj tak sa často stretávame s odmietavým prístupom k nemu. Vedenie podniku rozhoduje o úspechu či neúspechu TQM už pri stanovení politiky kvality a pri jej dodržiavaní. Prekážkou úspešného zavedenia TQM môže byt' vrcholový manažment, napríklad pri nedostatku presvedčenia o užitočnosti TQM, obave zo straty autority, neochote ku zmenám alebo neschopnosti tímovej práce. [11]

Ďalším trendom, o ktorom je potrebné sa zmienit' je portfóliová matica BCG, ktorá vyjadruje postavenie produktu na trhu podl'a miery rastu trhu (na vertikálnej osi - ukazovatel' trhovej príležitosti) a relatívneho podielu na trhu (na horizontálnej osi - ukazovatel' postavenia podniku na trhu). kategórií:

Podl'a kvadrantu, v ktorom sú produkty umiestnené, ich môžeme rozdelit’ do týchto

- psy - tieto produkty majú nízku mieru rastu a malý podiel na trhu, pre podnik nie sú rentabilné a je výhodnejšie od nich upustit';

- otázniky - majú malý podiel na trhu, ale vysokú mieru rastu, vyžadujú vel'ké investičné prostriedky;

- hviezdy - sú to najlepšie produkty s vysokou mierou rastu a významným podielom na trhu;

· dojné kravy - majú vysoký podiel na trhu, ale vel’mi nízku mieru rastu, preto časom "zvädnú".

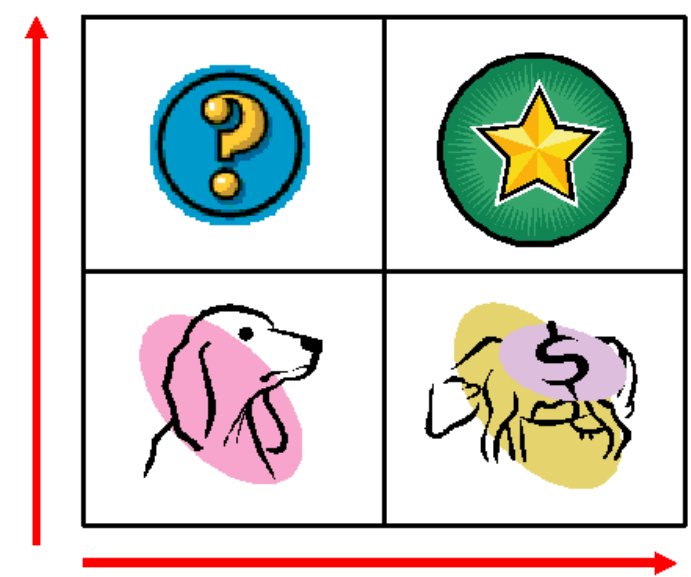

Obr. č. 1: Portfóliová matica BCG [8] stratégií:

Podl'a tohto rozdelenia produktov sa môže podnik rozhodnút' pre niektoré zo štyroch

- zvyšovat' podiel na trhu,

- udržat' súčasný podiel na trhu,

- znižovat' podiel na trhu,

- opustit' trh. [11] 
Všetky tieto hore uvedené manažérske trendy sa využívali v praxi posledných štyridsat' rokov. Avšak v poslednej dobe, aj ked' si nemôžeme byt' istí kam sa svet podnikania manažmentu uberá môžeme povedat', že jedným z významných trendov, ktorý naberá na význame a dostáva sa do popredia je manažment znalostí a s tým súvisiaca produktivita znalostí. Hlavnou výzvou manažmentu do budúcnosti je urobit' znalosti produktívnymi.

\section{Súčasnost'}

Dvadsiate prvé storočie je mnohými odborníkmi charakterizované ako storočie informácií. Do popredia sa dostávajú informácie, pretože sú základom znalostí, ktoré sa stávajú najdôležitejšou formou kapitálu podniku. K zvyšovaniu významu informácií podstatnou mierou prispieva aj dynamický rozvoj informačných a komunikačných technológií.

Tu však treba rozlišovat' rozdiel medzi pojmami ako sú znalosti, informácie a dáta. Informáciu v podstate predstavujú relevantné dáta obsahujúce určitý účel. Jedine uživatel' rozhodne, či sa dáta stanú informáciami alebo zostanú len jednoduchými dátami. V súvislosti s dátami a informáciami je potrebné charakterizovat' aj pojem znalosti. Znalost' je hodnota extrahovaná z informácie. Znalost' je informáciou, ktorou zamestnanec či manažér disponuje, rozumie jej a môže ju kedykol'vek na požiadanie opätovne získat'. [12]

Peter Drucker, americký klasik v manažmente a prvý z vizionárov ekonomiky vedomostí vo svojej publikácií „Vek diskontinuity“ v pät’desiatych rokoch predvídal objavenie ekonomiky vedomostí a uznanie vedomostí ako základného zdroja produktivity. Podl'a neho základným výrobným prostriedkom už nebudú prírodné zdroje (pôda), kapitál alebo práca $\mathrm{v}$ zmysle výroby a prepravy hmotných statkov, ale základným ekonomickým zdrojom a výrobným prostriedkom sa stanú vedomosti (znalosti). Takisto tvrdil, že d'alší ekonomický rast sa už nebude môct' zabezpečovat' iba neustále rastúcim množstvom l'udských zdrojov, ale bude potrebné dosiahnut' zmenu v produktivite každého jednotlivca zmenou na „znalostného pracovníka“. [1]

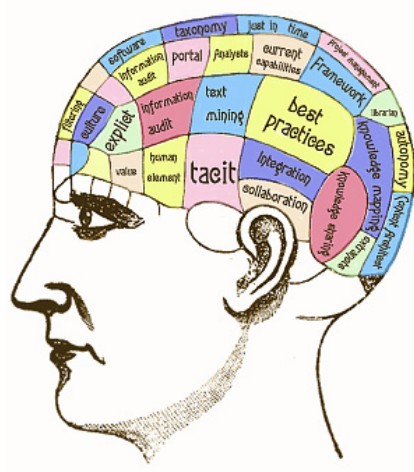

Hlavnou výzvou managementu vobdobí globalizácie a rozvíjania „IT technológií “ je urobit’ znalosti produktívnymi. Pred sto rokmi nikto nevedel ako urobit' manuálne pracujúceho zamestnanca produktívnym. Až na konci 19. storočia sa našla odpoved' na túto otázku: ,je treba pracovat' rozumnejšie, nie tvrdšie“. Z toho vyplýva, že pre každý podnik zostanú jedinou konkurenčnou výhodou l'udia disponujúci znalost'ami, ktoré budú vediet' primerane využívat'. [11]

Podl'a japonských ekonómov Nonaku a Takeuchiho, sa klasifikujú vedomosti v dvoch rovinách. Explicitné (formálne) môžu byt' vyjadrené v hmotnej podobe (knihy) a uložené napríklad do podnikového informačného systému. Rozhodujúci význam však majú vedomosti tacitné (skryté), ktoré sú ukryté $\mathrm{v}$ mysli, v správaní sa a $\mathrm{v}$ skúsenostiach človeka. Predovšetkým tento typ tacitných vedomostí je kl'účový a tvorí podstatu znalostného manažmentu. [9] 
Z hl'adiska tacitných vedomostí, ktoré sú podstatné môžeme znalostný manažment označit' ako procesný dej produkcie nových vedomostí, v ktorom sa riešia problémy, objavujú zákonitosti, produkujú sa objektívne intelektuálne novosti a inovácie. Znalostný manažment je teda procesom poznávania a pretvárania vedomostí." [9]

Samozrejme treba spomenút' aj otázky, ktoré so sebou manažment znalostí prináša. Vedomosti, ktoré majú v informačnej spoločnosti prioritu sú nemeratel'né. Chýba tvorivý dialóg medzi ekonómami, ktorí prešli na príliš fiškálne videnie sveta, a ostatnými odborníkmi (technikmi, manažérskymi pracovníkmi, právnikmi) o tom, ako oceňovat' vedomosti a ich nositel'ov - l'udí. Hodnota vedomostí sa doteraz viac oceňovala spätne, teda napríklad, kol'ko materiálu a financií sa ušetrilo zavedením novej technológie na základe vynálezu. Málokedy sa však vedomosti ocenili vopred - respektíve oceňujú sa len hmotné médiá obsahujúce vedomosti (knihy, sw-programy). [9]

Existujú rozdielne školy znalostného manažmentu:

- ekonomická škola,

- organizačná škola,

- strategická škola.

Ekonomická škola je zameraná na ochranu a využívanie firemných znalostí a intelektuálneho kapitálu ako zdroja pre tvorbu výnosov. Znalosti sú chápané ako aktíva, medzi ktoré patria patenty, obchodná značka, autorské práva a know-how. Táto škola je viac zameraná na využívanie znalostí ako ich skúmanie. V ekonomickej škole prebieha transfer znalostí na základe trhového mechanizmu ponuky a dopytu. [10]

Organizačná škola je zameraná na využívanie organizačných štruktúr a sietí na zdiel'anie a uchovávanie znalostí. Ide o kladenie dôrazu na tvorbu komunít spoločného záujmu, expertných skupín a virtuálnych tímov, ktoré môžu byt' interné, alebo externé. Organizačná škola zodpovedá popisu riadenia znalostí podl'a Nonaku. Významnú úlohu v organizačnej škole zohrávajú znalostní pracovníci.

Strategická škola chápe znalostný manažment ako integrálnu súčast’ podnikovej stratégie a súčasne je nástrojom pre zvýšenie konkurencieschopnosti. Prístup k znalostnému manažmentu závisí od perspektívy riadenia. Podla toho rozlišujeme perspektívu založenú na:

- informáciách a na prístupe $\mathrm{k}$ nim,

- technológiách, preferujúcu využívanie informačných a komunikačných technológií a znalostných aplikácií,

• kultúre, zohl'adňujúcu potrebu zmien podnikového spávania a kultúry. [10]

\section{Záver}

Tvorba, rozvoj, využívanie, zdiel'anie a zhodnocovanie znalostí má pre organizácie rozhodujúci význam tak z hl'adiska zabezpečenia ich d'alšieho rozvoja, ako aj z hl'adiska získania a udržania konkurenčnej výhody. Znalostný manažment (knowledge management) je prirodzeným evolučným krokom, výsledkom efektívneho využivania existujúcich a dôverne známych informačných technológií, ktoré napomáhajú prezentácii informácií, ktoré sú pre organizáciu relevantné, takým spôsobom, ktorý napomôže zamestnancom a manažérom získat' požadované informácie z konkrétnej nimi definovanej oblasti. 
V posledných rokoch možno pozorovat' narastajúci význam intelektuálneho kapitálu a jeho presadzovania sa ako najdôležitejšej formy kapitálu. Nástrojom, ktorý v rámci moderných manažérskych trendov využívajú popredné svetové firmy na riadenie a správu znalostného kapitálu, je práve znalostný manažment. Fakt, že sa zaoberá riadením znalostí l’udí, dáva predpoklad, že bude smerom dlhodobým a efektívnym. [1]

\section{Literatúra}

[1] KOKAVCOVÁ, D: Knižnica - roč. 7, č. 6 - 7 (2006)

[2] DRUCKER, P. Věk diskontinuity. Praha : Management Press, 2002.

[3] BREZINA L. Manažment vedomostí: realita za marketingovými sloganmi. Bratislava Trend. Info-trendy, č. 4/1999,

[4] DRUCKER, P.: Výzvy managementu pro 21. století. Praha:Management Press, 2000

[5] TRUNECEK, J.: Znalosti v roce 2001. Moderní ř́zení č. 11/2001 s.39-43

[6] VEBER, J.: Management: Základy, prosperita, globalizace. Management-Press Praha. 1998

[7] ŠTOFKOVÁ, J. a kol.: Manažment podniku, EDIS, Žilinská univerzita v Žiline 2007, ISBN: 978-8070-713-2

[8] www.decide-guide.com

[9] ZAJAC-VANKA, P.: Znalostný manažment - kl'úč k úspechu, Internetové vydanie týždenníka Slovo, č. 24, 2001

[10] www.mtf.stuba.sk

[11] modernirizeni.ihned.cz

[12] www.ictnews.sk

\section{Grantová podpora}

Príspevok je publikovaný v rámci spracovania projektu MVTS Pol'/SR/ŽU1/07 Moderné trendy strategického manažmentu a ich aplikácia vpodniku ako faktor zvyšovania konkurencieschopnosti. T-07-004-00 